\title{
Development of a PCR procedure for the detection of Baculovirus penaei in shrimp
}

\author{
Shiao Y. Wang ${ }^{1, *}$, Chao Hong ${ }^{1}$, Jeffrey M. Lotz ${ }^{2}$ \\ ${ }^{1}$ Department of Biological Sciences, University of Southern Mississippi, Hattiesburg, Mississippi 39406-5018, USA \\ ${ }^{2}$ Gulf Coast Research Laboratory, PO Box 7000, Ocean Springs, Mississippi 39566-7000, USA
}

\begin{abstract}
A PCR-based detection procedure for Baculovirus penaei (BP) was developed. Three forward and 3 reverse primers were designed to provide 6 primer-pair combinations with PCR products ranging in size from 196 to $933 \mathrm{bp}$. The expected amplification products were obtained when template DNA isolated from postlarval Penaeus vannamei experimentally infected with BP in the laboratory or from wild-caught BP-infected juvenile $P$. aztecus were used. DNA isolated from specific pathogen-free $P$ vannamei did not yield amplification products using the same PCR primers. The procedure used to prepare the sample for PCR was found to be critical because of the presence of unknown compounds in shrimp tissue that inhibited DNA polymerase. A suitable sample preparation procedure using proteinase $\mathrm{K}$ digestion, phenol/chloroform extraction and ethanol precipitation is described
\end{abstract}

KEY WORDS: Baculovirus - Baculovirus penaei $(B P) \cdot P C R \cdot$ Disease $\cdot$ Shrimp

\section{INTRODUCTION}

The Baculoviridae is a family of occluded DNA viruses pathogenic for arthropods belonging predominantly to the insect order Lepidoptera (Blissard \& Rohrmann 1990). A crustacean baculovirus was first discovered in 1974 in the pink shrimp Penaeus duorarum and named Baculovirus penaei (BP) (Couch 1974a, b). BP, also named Penaeus vannamei single nuclear polyhedrosis virus (PvSNPV) (Francki et al. 1991), is now known to infect wild penaeid shrimp in the Americas ranging from the northern Gulf of Mexico to central Brazil along the Atlantic Coast, from Mexico to Peru along the Pacific Coast, and Hawaii (Lightner \& Redman 1991, Lightner 1993).

BP infects cells of the hepatopancreatic and midgut epithelium (Couch 1974a, b, 1989, Johnson \& Lightner 1988). During viral replication, newly synthesized virions may be either free or occluded within tetrahedral crystalloid bodies, termed occlusion bodies, which are composed primarily of the protein polyhedrin (Summers 1977, Rohrmann 1986). Histopathologic damage

\footnotetext{
·E-mail: sywang@whale.st.usm.edu
}

occurs when hepatopancreatic and midgut epithelial cells are destroyed during occlusion body formation and subsequent eruption from host cells (Couch 1981, 1989).

Epizootics of $\mathrm{BP}$ in intensive culture systems can result in high mortality of larval and postlarval shrimp when high density promotes the development and spread of the disease (LeBlanc \& Overstreet 1990, Stuck \& Overstreet 1994). An effective way to limit the occurrence of the disease is by preventing the introduction of BP-infected shrimp into a population. To diagnose $\mathrm{BP}$, the simplest method is to examine fresh squashes of the hepatopancreas or feces for the presence of occlusion bodies by light microscopy (Overstreet et al. 1988). However, if occlusion bodies are rare or not present, as is the case, for example, during the prepatent stage of an infection (Blissard \& Rohrmann 1990), then detection of BP infection is problematic. Two molecular techniques for BP diagnosis have been published. Lewis (1986) described an immunosorbent assay and Bruce et al. $(1993,1994)$ described an in situ hybridization procedure for detecting BP.

The goal of the present study was to develop a procedure to detect $\mathrm{BP}$ using the polymerase chain reaction (PCR) (Saiki et al. 1985, Mullis et al. 1986). PCR 
offers many advantages for disease diagnosis (see reviews by Henson \& French 1993, Jones \& Bej 1994. Martin 1994). With regard to BP, important advantages include its extreme sensitivity, pathogen specificity, ease of sample preparation, and the general availability of reagents. The procedure would be useful not only for disease diagnosis but also for studying the basic biology of BP (Stuck \& Wang in press).

\section{MATERIALS AND METHODS}

High health Penaeus vannamei nauplii from U.S. Marine Shrimp Farming Program Population 1 (Wyban 1992) were obtained from The Oceanic Institute, Honolulu, Hawail, and reared to the postlarvae stage following the procedure of Stuck \& Overstreet (1994) Beginning at the mysis stage, fresh squashes of the hepatopancreas of at least 10 shrimp were examined by light microscopy every 2 or $3 \mathrm{~d}$ to verify that these shrimp were free of BP occlusion bodies and thus were not accidentally infected with BP. When the postlarvae were $7 \mathrm{~d}$ old, approximately $25 \%$ of the postlarvae were used as the source of DNA for the negative control whereas the remaining postlarvae were inoculated with BP. The postlarvae were stocked at a density of approximately $50 \mathrm{I}^{-1}$ and inoculated with BP by adding homogenized infective stock (postlarvae previously infected with $\mathrm{BP}$ and stored at $-80^{\circ} \mathrm{C}$ ) at a concentration of $10 \mathrm{mg} \mathrm{l}^{-1}$ of culture water. The BP infective stock was originally collected in Ecuador (see Overstreet et al. 1988). The progress of infection was monitored by examining fresh squashes of 10 postlarval hepatopancreases every $12 \mathrm{~h}$. Infected postlarvae were harvested $48 \mathrm{~h}$ post infection at which time $80 \%$ of the shrimp contained BP occlusion bodies. A portion of the $\mathrm{BP}$-exposed postlarvae was frozen at $-80^{\circ} \mathrm{C}$ and the rest was used immediately as the source of DNA for the positive control. Postlarvae used for negative and positive control DNA were homogenized in a $4 \mathrm{M}$ guanidine thiocyanate solution containing $50 \mathrm{mM}$ Tris- $\mathrm{HCl}$ $\mathrm{pH} 7.5,10 \mathrm{mM}$ EDTA, 2\% sodium lauryl sarcosine and $1 \% \beta$-mercaptoethanol. DNA was isolated from the homogenate using the IsoQuick Nucleic Acid Extraction Kit (MicroProbe Corp., Bothell, WA, USA). DNA purified from the insect baculovirus Autographa californica nuclear polyhedrosis virus was purchased from Invitrogen Corp. (San Diego, CA, USA).

Juvenile Penaeus aztecus (approximately 30 to $60 \mathrm{~mm}$ total length) were collected by trawling in the Davis Bayou estuary in Ocean Springs, Mississippi, USA. To determine whether each shrimp was infected with BP, a small portion of the hepatopancreas from each shrimp was squashed and examined by light microscopy for the presence of occlusion bodies. The re- maining hepatopancreas was quick frozen in liquid nitrogen and stored at $-80^{\circ} \mathrm{C}$ for later analysis by PCR.

The protocol for PCR sample preparation was developed using the procedure of Malitschek \& Schartl (1991). This procedure was selected for development because the enzyme used for sample digestion, proteinase $K$, can be heat inactivated and the digestion buffer does not inhibit PCR. Thus, at least in theory, shrimp samples can be used in PCR reactions directly after digestion without further processing, saving considerable time. Each shrimp hepatopancreas was digested in a digestion buffer containing $50 \mathrm{mM} \mathrm{KCl}, 10 \mathrm{mM}$ Tris-HCl $(\mathrm{pH} 8.3), 0.1 \mathrm{mg} \mathrm{ml}^{-1}$ gelatin, $0.45 \%$ Nonidet P-40, $0.45 \%$ Tween-20 and $80 \mu \mathrm{g} \mathrm{ml}^{-1}$ proteinase $\mathrm{K}$. The hepatopancreas was dispersed in the digestion solution in $1.5 \mathrm{ml}$ microcentrifuge tubes using the tip of an air-displacement pipette as a pestle. Forcing the tissue sample through the small orifice of the pipette tip while pipetting the mixture up and down aided in dispersing the sample. The volume of the digestion buffer used depended on the size of the shrimp. In general, $75 \mu$ l were used for the hepatopancreas of a postlarva of approximately 10 to $15 \mathrm{~mm}$ total length and volumes up to $400 \mu \mathrm{l}$ were used for the hepatopancreas of a juvenile of approximately $50 \mathrm{~mm}$ total length. After dispersing the tissue sample in digestion buffer, each sample was heated at $60^{\circ} \mathrm{C}$ for $1 \mathrm{~h}$ and then at $95^{\circ} \mathrm{C}$ for $10 \mathrm{~min}$. The samples were then centrifuged at $12000 \times g$ for 2 min and the supernatant transferred to a new tube for storage on ice.

To remove proteins in the sample, $50 \mu l$ of the digest were diluted with $150 \mu$ l of dilution buffer $(10 \mathrm{mM}$ Tris$\mathrm{HCl}, \mathrm{pH} 8.0,0.1 \mathrm{mM}$ EDTA) and extracted with $200 \mu \mathrm{l}$ of phenol: isoamyl alcohol:chloroform (PIC) (25:1:24). After vortexing the sample for $5 \mathrm{~s}$, the tube was left at room temperature for 5 min and then centrifuged at $12000 \times g$ for $2 \mathrm{~min}$. To minimize the risk of contaminating the sample with possible inhibitory compounds in the interphase between the aqueous and organic phases, only $160 \mu \mathrm{l}$ of the aqueous (upper) phase was transferred to a new $0.6 \mathrm{ml}$ microcentrifuge tube. The extraction step was repeated with an equal volume of chloroform $(160 \mu \mathrm{l})$ and only $130 \mu \mathrm{l}$ of the sample (aqueous phase) was transferred to a new tube. To precipitate the DNA, $20 \mu \mathrm{g}$ of glycogen $(1 \mu \mathrm{l}$ of a $20 \mathrm{mg}$ $\mathrm{ml}^{-1}$ stock), one-half volume $(65 \mu \mathrm{l})$ of $7.5 \mathrm{M}$ ammonium acetate and 3 volumes $(390 \mu \mathrm{l})$ of ethanol were added to the tube, mixed and then stored at $-20^{\circ} \mathrm{C}$ for at least 1 h. Each sample was then centrifuged at $12000 \times g$ for 5 min to pellet the DNA. The pellet was rinsed with $200 \mu \mathrm{l}$ of $70 \%$ ethanol to remove residual ammonium acetate and then dried under vacuum for $10 \mathrm{~min}$. The DNA pellet was dissolved in $30 \mu \mathrm{l}$ of dilution buffer prior to PCR. Solubilization of the DNA was 
facilitated by heating the sample at $50^{\circ} \mathrm{C}$ for $10 \mathrm{~min}$ with frequent mixing. The DNA samples were stored at $-20^{\circ} \mathrm{C}$.

DNA concentrations were determined using fluorescence spectroscopy. One $\mu$ l of sample was added to $600 \mu \mathrm{l}$ of $1 \times \mathrm{SSC}(150 \mathrm{mM} \mathrm{NaCl}$ and $15 \mathrm{mM} \mathrm{Na}$ citrate) containing $2 \mu \mathrm{g} \mathrm{ml}^{-1}$ bis-benzimide (Molecular Probes, Eugene, OR, USA). The fluorescence of the sample at $450 \mathrm{~nm}$ was determined at an excitation wavelength of $360 \mathrm{~nm}$ using a Hitachi F-2000 fluorescence spectrophotometer (Hitachi, Inc., Tokyo, Japan). The DNA concentration of the sample was determined by comparing the fluorescence of the sample to those of standards prepared using salmon sperm DNA (Sigma Chemical Co., St. Louis, MO, USA).

The PCR primers were derived from a putative BP polyhedrin CDNA sequence (Table 1, Fig. 1) (Lin \& Wang 1993). Three forward primers (BPA, BPD and $B P E$ ) and 3 reverse primers (BPF, $B P B$ and $B P($ ) were designed which provided 6 primer-pair combinations with expected PCR products that ranged in size from 196 to $933 \mathrm{bp}$. The primers were synthesized commercially by either National Biosciences (Plymouth, MN, USA) or Keystone Laboratories, Inc. (Menlo Park, CA, USA). The melting temperatures of the primers were calculated by the manufacturers using the nearest neighbor method (Richlik et al. 1990). The 2 thermal

Table 1. Nucleotide sequence and melting temperature (TM) of the 6 primers used for PCR-based BP diagnosis

\begin{tabular}{|lcc|}
\hline Primer & Nucleotide sequence & Tm $\left({ }^{\circ} \mathrm{C}\right)$ \\
\hline BPA & 5'GATCTGCAAGAGGACAAACC & 61 \\
BPB & 5'ATCGCTAAGCTCTGGCATCC & 64 \\
BPD & 5'TGTTCTCAGCCAATACATCG & 62 \\
BPE & 5'TACATCTTGGATGCCTCTGG & 63 \\
BPF & 5'TACCCTGCATTCCTTGTCGC & 68 \\
BPG & 5'ATCCTGTTTCCAAGCTCTGC & 64 \\
& & \\
\hline
\end{tabular}

stable DNA polymerases used, AmpliTaq and Tbr, were equally effective in amplifying DNA and were obtained from Perkin Elmer (Norwalk, CT, USA) and Amresco Inc. (Solon, OH, USA), respectively. Thermal cycling was performed using a water-cooled single block thermal cycler from Ericomp, Inc. (San Diego, CA, USA).

Prior to PCR, the D $\mathrm{X}$.t in each sample was denatured by heating in a boiling water bath for 3 min followed by quick chilling in ice-water. Generally, $25 \mu \mathrm{l}$ PCR reactions were performed. Each $25 \mu \mathrm{l}$ reaction contained the appropriate reaction buffer provided by the manufacturer of the DNA polymerase, $5 \mathrm{mM}$ of each dNTP, $5 \mu \mathrm{M}$ of each primer, $1.5 \mathrm{mM} \mathrm{MgCl}_{2}, 0.5$ to 1 unit of DNA polymerase and denatured DNA. After heating the sample for $3 \mathrm{~min}$ at $95^{\circ} \mathrm{C}, 30 \mathrm{PCR}$ cycles were performed followed by a final elongation step of $5 \mathrm{~min}$ at $72^{\circ} \mathrm{C}$. Each of the 30 cycles consisted of a DNA melting step at $94^{\circ} \mathrm{C}$, a primer annealing step at $60^{\circ} \mathrm{C}$ and a primer elongation step at $72^{\circ} \mathrm{C}$.

The PCR products were separated by size using $2 \%$ agarose gel electrophoresis. Ten $\mu l$ of each PCR reaction was typically loaded per lane. Each gel was stained after electrophoresis with ethidium bromide (1 $\mu \mathrm{g} \mathrm{ml} \mathrm{m}^{-1}$ ) for $15 \mathrm{~min}$, the DNA visualized using a $302 \mathrm{~nm}$ UV transilluminator and the gel photographed. The sizes of the DNA products were determined relative to those of DNA size markers. The markers were obtained by digesting the plasmid pGEM $7 \mathrm{Zf}+$ with Hinfl. The sizes of the 5 largest fragments are 1129 , $517,452,396$ and 299 bp. Relative comparisons of the amount of amplification product among lanes within the same gel were made by comparing the brightness of the DNA fragment on the photograph. An image of the gel was captured using a TrueVision Targa-M8 Frame Grabber and analyzed using the Java video analysis software (Jandell Scientific, Corte Madera, CA, USA).

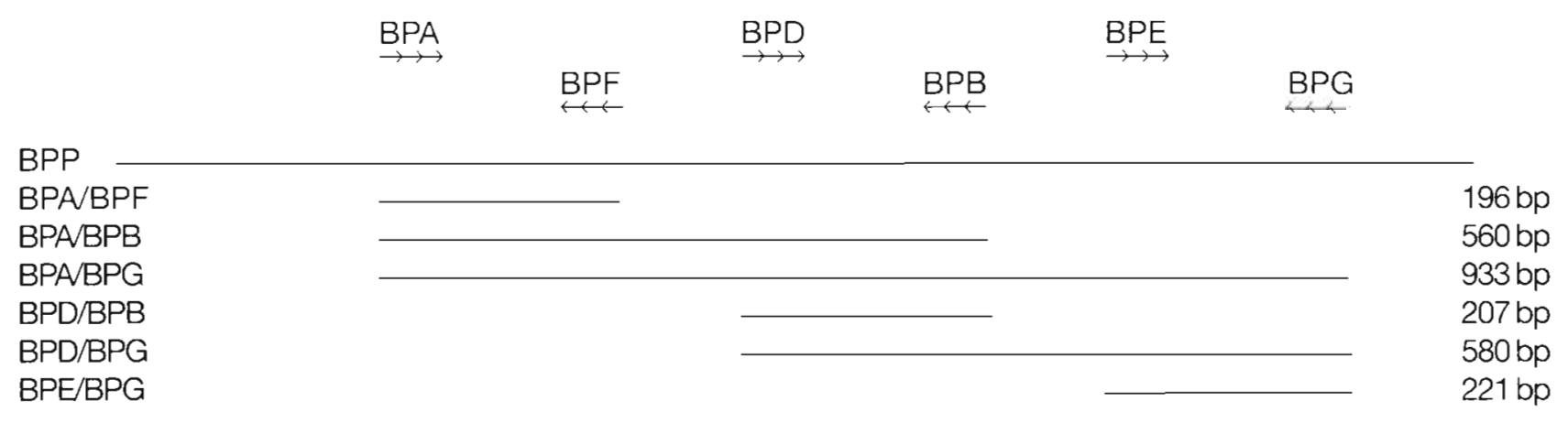

Fig. 1 The position of primers relative to a putative BP polyhedrin cDNA. BPP represents a cloned insert of approximately $1430 \mathrm{bp}$. The position of the PCR products relative to BPP and to each other, and the expected size of the 6 PCR products, are shown below BPP 


\section{RESULTS}

Each of the 6 PCR primer pairs was useful in the diagnosis of BP in Penaeus vannamei. Each pair primed the synthesis of a DNA fragment of the expected size only when DNA isolated from BP-infected shrimp was used as template (Fig. 2). In contrast, amplification reactions in which non-infected shrimp DNA was used as template failed to produce PCR products. A control reaction containing DNA polymerase but lacking $\mathrm{BP}$ infected shrimp DNA failed to produce PCR products, demonstrating that the $P C R$ reagents were not contaminated with DNA (Fig. 2, lane C)

$\mathrm{BP}$ appears to be closely related, if not identical, to the baculovirus that infects Penaeus aztecus. The PCR producis primed by inte 6 primer pairs wete incisinguishable in size between the 2 species (Fig. 3, lanes I and $Z$ ). On the other hand, BP appears to be quite different from a baculovirus that infects insects. None of the 6 primer pairs primed DNA synthesis when the template DNA used in the reaction was that of the insect baculovirus Autographa californica nuclear polyhedrosis virus (AcMNPV) (Fig. 3, lane A). In a reciprocal experiment, BV1 and BV2, primers designed to prime the synthesis of a $385 \mathrm{bp}$ fragment in AcMNPV failed to prime DNA synthesis when BPinfected $P$. vannamei DNA was used as template but successfully produced DNA of the expected size when ACMNPV DNA was used in the amplification reaction (Fig. 3).

Although thermal cycling was routinely performed using $60^{\circ} \mathrm{C}$ for the annealing temperature, 50 and $55^{\circ} \mathrm{C}$ also yielded specific products (Fig. 4). PCR products were not synthesized in control reactions in which

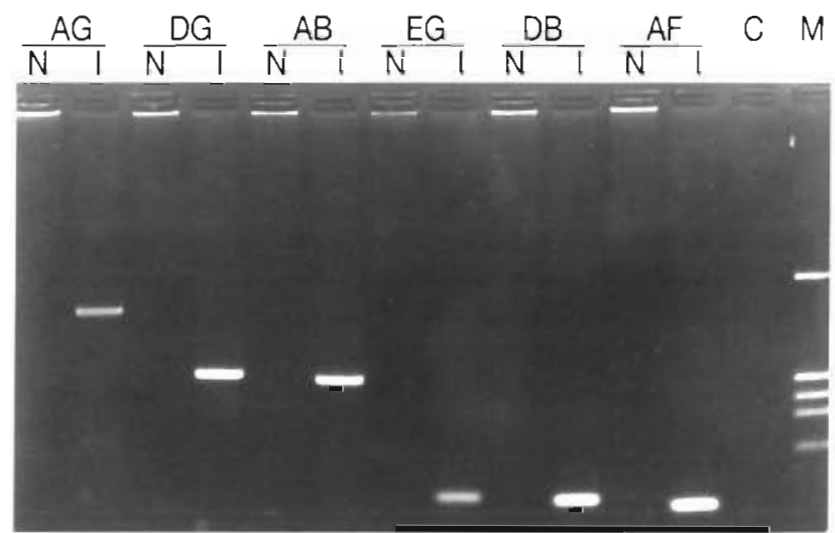

Fig. 2. Specificity of PCR in diagnosing the presence of BP in shrimp. N: Penaeus vannamei not infected with BP; I: $P$. vannamei infected with BP. C: control reaction without template DNA; $M$ : markers, pGEM $7 \mathrm{Zf}+$ digested with HinfI. The sizes of the 5 largest fragments are $1129,517,452,396$ and $299 \mathrm{bp}$ $A G, D G, A B, E G, D B$ and $A F$ represent the primer pairs used Each PCR reaction contained $100 \mathrm{ng}$ of template DNA.

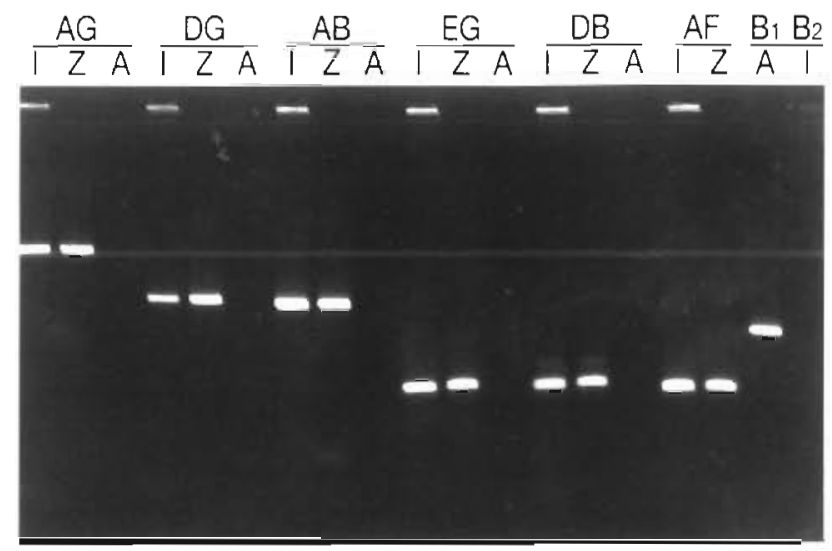

Fig. 3. Amplification products using ACMNPV and BP-infected penaeid shrimp DNA as template. AG, DG, AB, EG, DB, AF and $B_{1} B_{2}$ represent the primer pairs used. I: $B . P$-infected Penaeus vannamei (40 ng DNA); $Z$ : BP-infected $P$. aztecus (100 ng DNA); A: ACMNPV (10 ng DNA)

either BP-infected shrimp DNA or DNA polymerase was omitted, indicating that the DNA fragments produced were results of template-dependent DNA amplification (Fig. 4, lanes $\mathrm{C}_{1}$ and $\mathrm{C}_{2}$ ).

Because all 6 primer pairs were useful for BP diagnosis, further studies were conducted using the primer pair BPA/BPB only. DNA yield increased as the primer concentration increased from 0.05 to $0.2 \mu \mathrm{M}$ (Fig. 5). Increasing the primer concentration above $0.2 \mu \mathrm{M}$ did not result in significant increases in yield but, more importantly, there was no evidence of nonspecific priming at $1 \mu \mathrm{M}$, the highest primer concentration tested. Visible amounts of primer-dimers were produced at 0.6 to $1 \mu \mathrm{M}$

The template denaturation and primer annealing and extension times did not appear to be critical. Denaturation and annealing times of 15 and $30 \mathrm{~s}$ and extension times of $15,30,45$ and $60 \mathrm{~s}$ were tested. All combinations produced visible amounts of the expected $560 \mathrm{bp}$ PCR product (Fig. 6). The least amount of PCR product was produced using denaturation, annealing and extension times of $15 \mathrm{~s}$ each. Other combinations of reaction times produced quantities of PCR products that were difficult to distinguish visually. Digital analysis of a photograph of the gel indicated that the intensity of the stained amplification product generally increased with increasing extension times (data not shown). This increase was most pronounced using denaturation and annealing times of $15 \mathrm{~s}$ each. The intensity of the stained PCR product increased from 47.2 to 62.1 relative gray scale units as the extension times increased from 15 to $60 \mathrm{~s}$. To verify that longer reaction times result in increased DNA yields, the amounts of DNA produced using identical amplification reactions but denaturation, annealing and ex- 


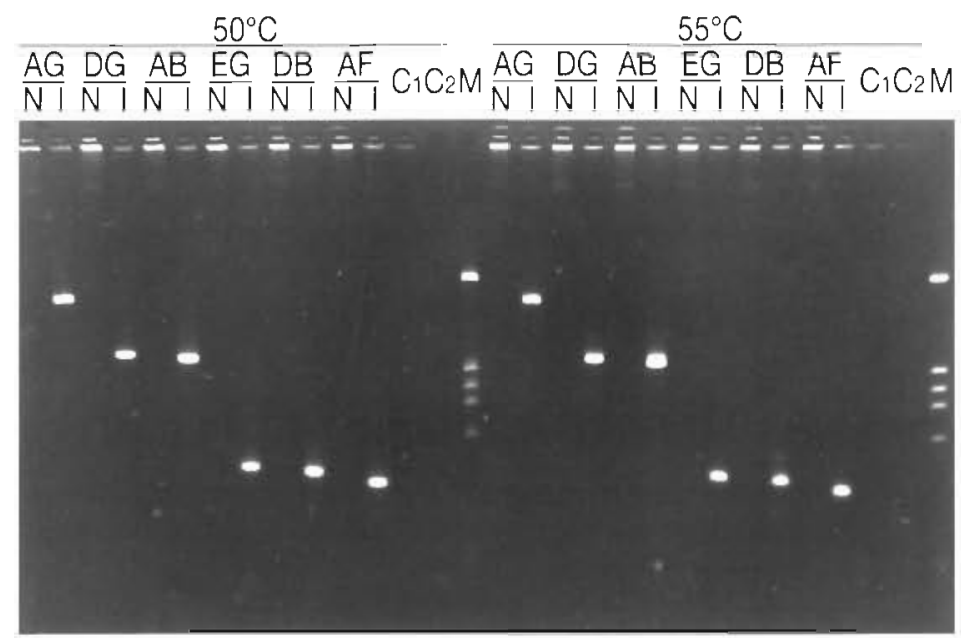

Fig. 4. Specificity of PCR using annealing temperatures of 50 and $55^{\circ} \mathrm{C}$ for $\mathrm{BP}$ diagnosis. The primer pairs used ( $A G, D G, A B, E G, D B$ and $A F$ ) in the different reactions are listed below the annealing temperatures. $\mathrm{N}$ : Penaeus vannamei not infected with $\mathrm{BP}$; I: P. vannamei infected with BP. $C_{1}$ : control reactions without template $D_{N A} C_{2}$ : control reactions without DNA polvmerase; $M$ : markers, pGEM $7 \mathrm{Zi}+$ digested with Hinfl. The sizes of the 5 largest fragments are 1129, 517, 452, 396 and $299 \mathrm{bp}$. Each PCR reaction contained $100 \mathrm{ng}$ of template DNA

tension times of 15, 15 and $15 \mathrm{~s}$ and 30,30 and $60 \mathrm{~s}$, respectively, were quantified fluorometrically. The longer reaction times produced $44 \%$ more PCR product. The yield was $620 \pm 60 \mathrm{ng}$ DNA (mean \pm SEM; $\mathrm{n}=6$ ) per $25 \mu \mathrm{l}$ reaction using the shorter reaction times and $890 \pm 40 \mathrm{ng}$ DNA using the longer reaction times.

The yield of PCR products is partly dependent on the amount of template DNA in the reaction. Using DNA isolated from BP-infected Penaeus vannamei postlarvae, the minimum quantity of template needed to produce sufficient amounts of DNA for visualization in an agarose gel stained with ethidium bromide was $10 \mathrm{ng}$ (Fig. 7). The yield of the expected $560 \mathrm{bp}$ fragment increased with increasing amounts of template and reached a maximum when $60 \mathrm{ng}$ of DNA was used. Further increases in template quantity did not produce more product and, perhaps more importantly, did not produce visible amounts of nonspecific amplification products.

Although $10 \mathrm{ng}$ of template DNA were sufficient to detect BP infection in Penaeus vannamei postlarvae, increased amounts of template DNA were necessary to detect $\mathrm{BP}$ infection by PCR in juvenile $P$. aztecus (Fig. 7). Using DNA isolated from 2 juvenile BPinfected $P$. aztecus, sufficient DNA for visualization was produced only when $300 \mathrm{ng}$ of template was used for one shrimp and $50 \mathrm{ng}$ of template for the other (Fig 7, lanes 10 and 12, respectively). For the shrimp in which $50 \mathrm{ng}$ of template DNA was needed to produce visible amounts of amplified DNA, increasing the quantity of template in the reaction to $100 \mathrm{ng}$ increased the yield substantially (Fig 7, lanes 12 and 13)

The procedure used to prepare each sample prior to PCR is critical to the success of the amplification reaction. We tested the use of Chelex-100, a resin known to be useful for preparing difficult samples for PCR (Walsh et al. 1991), but obtained occasional false negative results (data not shown). Our preferred sample preparation protocol is to digest the sample with proteinase $\mathrm{K}$, extract with phenol/chloroform and precipitate the DNA with ethanol. Although it would be much simpler and quicker to use the samples immediately after proteinase $\mathrm{K}$ digestion, some BP-infected shrimp samples produced the expected PCR product only after the sample had been extracted with phenol/ chloroform and the nucleic acids precipitated with ethanol. An example of this effect is shown in Fig. 8 using 6 BP-infected shrimp samples. A portion of each sample was removed after each of the 3 treatment steps for DNA amplification (labelled D, E and P in Fig 8, respectively). After determining the quantity of DNA in each sample, $100 \mathrm{ng}$ of template DNA were used in a PCR reaction. DNA in sample 1 could be amplified immediately after digestion with proteinase K. Samples 3 and 5 also contained DNA that could be amplified after digestion with proteinase $\mathrm{K}$ but the amount

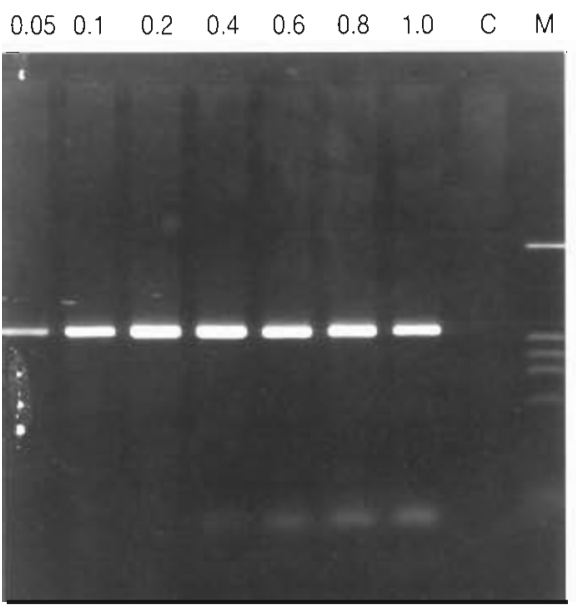

Fig. 5. Effect of primer concentration on the yield of PCR products. The numbers represent the final concentration $(\mu M)$ of primers $\mathrm{BPA}$ and $\mathrm{BPB}$ in $25 \mu \mathrm{PCR}$ reactions that were otherwise identical. Each PCR reaction contained $100 \mathrm{ng}$ of $\mathrm{BP}$-infected Penaeus vannamei DNA as template. C: control reaction without primers; $M$ : markers, $\mathrm{pGEM} 7 \mathrm{Zf}+$ digested with Hinfl. The sizes of the 5 largest fragments are 1129, 517 . 452,396 and $299 \mathrm{bp}$ 


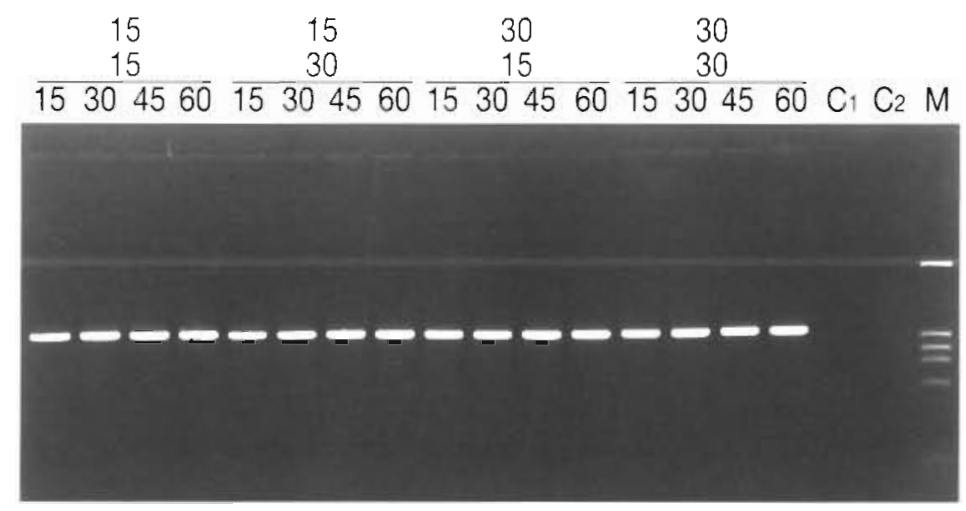

Fig. 6. Effects of melting, annealing and extension times on the yield of PCR products. Melting, annealing and extension steps were carried out at 94,60 and $72^{\circ} \mathrm{C}$, respectively. The upper, middle and lower numbers represent the melting, annealing and extension times in seconds, respectively. Each PCR reaction contained $100 \mathrm{ng}$ of BP-infected shrimp DNA as template. $C_{1}$ : control reaction without template DNA. $C_{2}$ : control reaction without DNA polymerase. M: markers; pGEM $7 \mathrm{Zf}+$ digested with HinfI. The sizes of the 5 largest fragments are 1129, 517 . 452,396 and $299 \mathrm{bp}$

of amplification product was barely detectable in the ethidium bromide stained gel. Amplification of the same samples was greatly enhanced after phenol/chloroform extraction and ethanol extraction. Sample 4 contained DNA that could be amplified after extraction with phenol/chloroform; ethanol precipitation was not necessary. Samples 2 and 6 could be amplified only after both phenol/chloroform extraction and ethanol precipitation. To summarize, DNA from only 3 of the 6 shrimp could be amplified directly after proteinase $\mathrm{K}$ digestion. DNA from an additional shrimp could be amplified only after proteinase $\mathrm{K}$ digestion and phe-

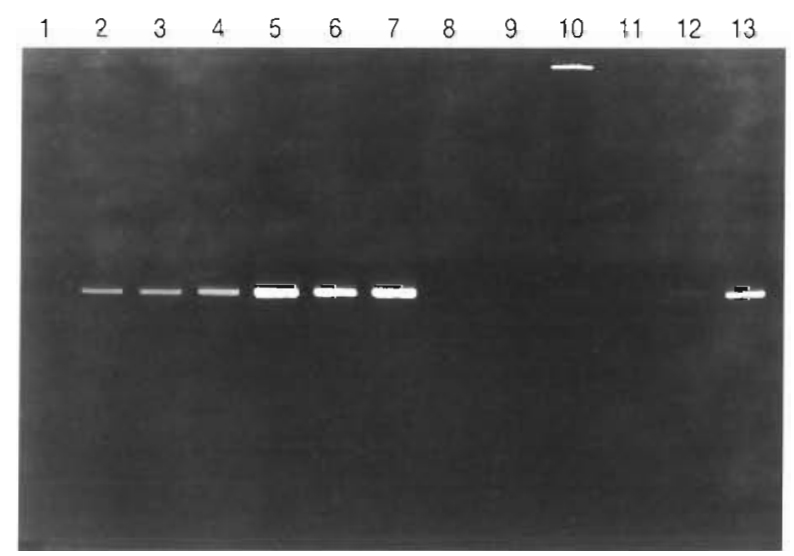

Fig. 7. Effect of DNA template concentration on the yield of PCR products. Lanes 1 to $7: 5,10,20,40,60,80$, and $100 \mathrm{ng}$, respectively, of template DNA extracted from a single BPinfected Penaeus vannamei. Lanes 8 to 10: 10, 100 and 300 ng. respectively, of template DNA extracted from a single BPinfected $P$, aztecus. Lanes 11 to $13: 10,50$ and $100 \mathrm{ng}$, respectively, of template DNA from a different BP-infected $P$. aztecus nol/chloroform extraction. DNA from the remaining 2 shrimp could be amplified only after proteinase $K$ digestion, phenol/ chloroform extraction and ethanol precipitation. It is clear that shrimp tissues contain varying quantities of an inhibitory compound that could be removed by phenol/chloroform extraction and ethanol precipitation.

The effect of this unknown inhibitor on DNA polymerase is demonstrated clearly in a mixing experiment shown in Fig 9. Lanes 1 to 5 contain the product of DNA amplification in which $100 \mathrm{ng}$ of 'clean' DNA and increasing amounts of a digested but unextracted sample were used as template. The 'clean' sample refers to DNA that was obtained from a $B P$ infected shrimp hepatopancreas that was proteinase $\mathrm{K}$ digested, phenol extracted and the DNA ethanol precipitated. The digested sample was sample 6 of Fig. 8 and was known to contain a polymerase inhibitor, i.e the sample produced the expected DNA fragment during PCR when extracted and precipitated but failed to do so when the extraction and precipitation steps were omitted. The 'clean' DNA alone yielded an amplification product of the expected size (Fig. 9, lane 1). Increasing the amount of digested sample from 10 to 50 and $100 \mathrm{ng}$ gradually reduced the yield of PCR products (Fig. 9, lanes 2 to 4) and $200 \mathrm{mg}$ of digested sample inhibited the polymerase activity completely (Fig. 9, lane 5). This inhibitory effect could not be

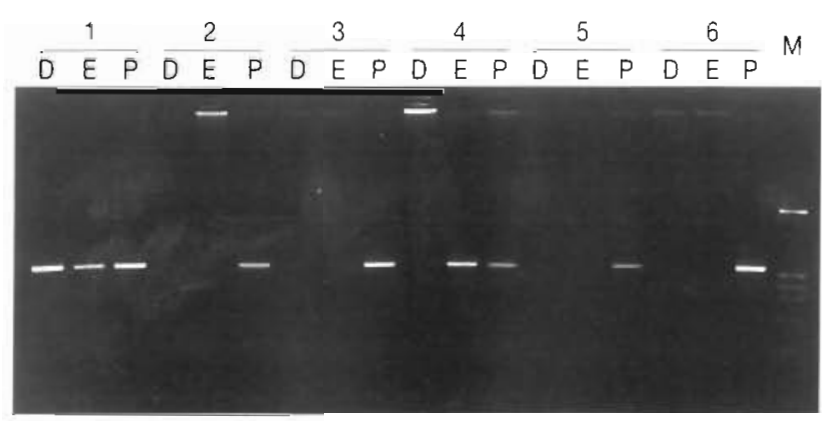

Fig. 8. Effects of sample preparation procedures on the effectiveness of PCR for BP diagnosis; D: shrimp hepatopancreas digested with proteinase $\mathrm{K}$ only; $\mathrm{E}$ : shrimp hepatopancreas digested with proteinase $\mathrm{K}$ and then extracted with phenol chloroform. P: shrimp digested with proteinase $\mathrm{K}$, extracted with phenol/chloroform and the DNA precipitated with ethanol. The numbers represent 6 different BP-infected shrimp used. Each $25 \mu \mathrm{l}$ PCR reaction contained $100 \mathrm{ng}$ of BP-infected shrimp DNA as template and 5 pmol of primers BPA and BPB. Lanes 3D, 3E, 4D and 4E contain the expected 560 bp DNA but the amount is too small to be seen clearly in the photograph of the gel. M: markers, pGEM $7 \mathrm{Zf}+$ digested with Hinfl. The sizes of the 5 largest fragments are 1129,517 , 452,396 and 299 bp 


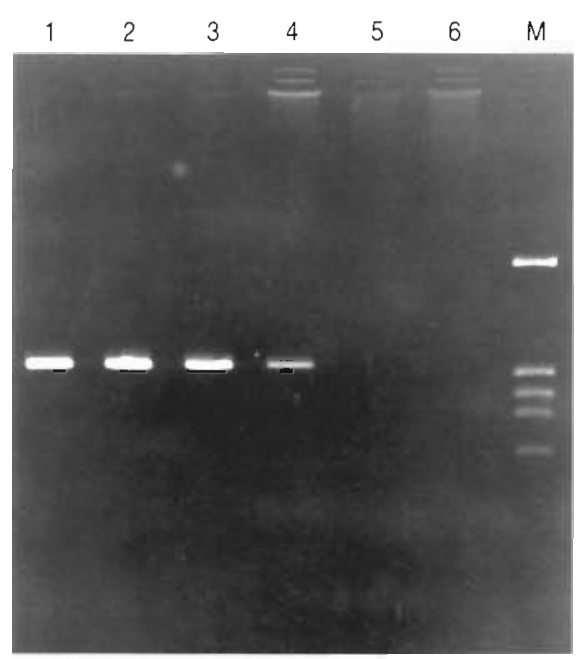

Fig. 9. Inhibitory effect of a digested but unextracted shrimp hepatopancreas sample on PCR. Lanes 1 to 5: $100 \mathrm{ng}$ of 'clean' (proteinase K digested, phenol extracted and ethanol precipitated) template DNA from a BP-infected shrimp and $0,10,50$, 100 and $200 \mathrm{ng}$, respectively, of digested but not extracted DNA from a different BP-infected shrimp known to contain a PCR inhibitor. Lane 6 is the same as lane 5 except $580 \mathrm{ng}$ of digested, phenol extracted and ethanol precipitated template DNA were used. M: markers, pGEM $7 \mathrm{Zf}+$ digested with Hinfl. The sizes of the 5 largest fragments are $1129,517,452,396$ and $299 \mathrm{bp}$

reversed by increasing the amount of positive control DNA to $580 \mathrm{ng}$ (Fig 9, lane 6).

\section{DISCUSSION}

A PCR-based detection procedure has been developed for BP. The 6 primer pairs appear to be BPspecific as DNA products of the expected size were amplified when template DNA isolated from BPinfected Penaeus vannamei or $P$. aztecus was used. Amplification reactions using template DNA isolated from $P$ vannamei prior to BP-infection failed to produce the DNA products. The PCR primers were designed using the sequence of a putative BP polyhedrin cDNA (Lin \& Wang 1993). The specificity of the primers supports the findings of Lin \& Wang (1993) which showed that the cloned polyhedrin DNA sequence was transcribed in BP-infected $P$ vannamei but absent in non-infected shrimp. Of interest was the observation that these BP-specific primers failed to amplify DNA of the insect baculovirus AcMNPV and that AcMNPV polyhedrin-specific primers failed to amplify BP DNA. This observation supports an earlier suggestion by Lin \& Wang (1993) that the baculoviruses that infect crustaceans and insects are not evolutionarily related.
The purpose of testing the effects of different template denaturation, primer annealing and extension times was to determine whether sufficient PCR product could be produced for visualization using the shorter reaction times. Since the procedure uses 30 reaction cycles, a reduction in time at any of the steps would reduce the overall cycling time so that results may be obtained more quickly. Our results indicate that $15 \mathrm{~s}$ each for template denaturation, primer annealing and extension is sufficient to produce clearly visible amounts of PCR product using an aluminum block thermocycler and $0.6 \mathrm{ml} \mathrm{PCR} \mathrm{tubes.}$ However, to maximize the amount of PCR product produced, the primer extension time should be increased to $60 \mathrm{~s}$.

A concern in using PCR for disease diagnosis is the production of false positives where nonspecific PCR products are produced. Reaction parameters that promote false priming and accumulation of nonspecific products include low annealing temperatures, excess primers and excess template (Innis \& Gelfand 1990). These reaction parameters were tested to determine the likelihood of obtaining false positive results. Our general conclusion is that the detection procedure is quite robust and that one is unlikely to obtain false positives. The $\mathrm{Tm}$ of the primers used in the present study ranged from 61 to $68^{\circ} \mathrm{C}$. To standardize the detection procedure, an optimum annealing temperature of $60^{\circ} \mathrm{C}$ was determined empirically. Specific PCR products were also obtained using annealing temperatures of 50 and $55^{\circ} \mathrm{C}$, indicating that sequences similar to the primer sequences do not occur in the shrimp genome. Although we found the optimal primer concentration to be $0.2 \mu \mathrm{M}$, primer concentrations up to $1 \mu \mathrm{M}$ can be used without producing nonspecific PCR products. Visible amounts of what appear to be primer-dimers were observed at 0.6 to $1 \mu \mathrm{M}$ but their small size relative to the expected 560 bp PCR product allows easy distinction between the two.

The effect of excess template DNA is important not only with regard to the production of false positives but also with regard to the likelihood of producing false negatives where BP-infected shrimp escapes detection, an equal if not greater concern. Diagnosis of BP using PCR is dependent on the amount of BP DNA present in a mixed population of both BP and shrimp DNA. The ratio between $B P$ and shrimp DNA is not known at the time of diagnosis and thus the concern is to include sufficient viral DNA for amplification but not so much total DNA as to produce false positive results. It is possible to use too little DNA. Using the same DNA preparation from BP-infected postlarval Penaeus vannamei, the amplification reaction failed to produce the expected DNA fragment when $5 \mathrm{ng}$ of template DNA 
was used but was successful when at least $10 \mathrm{ng}$ was used in a $25 \mu l$ amplification reaction. We have not observed false positives (nonspecific amplification products) using up to $500 \mathrm{ng}$ of total DNA. Thus, if one is to err with regard to the amount of template DNA to use in diagnosing BP by PCR, one should err on the side of excess DNA.

For routine diagnosis of BP infection, it is more practical to use a fixed amount of sample rather than determining the DNA concentration of each sample prior to PCR and using a predetermined amount of DNA. Because the relative number of BP-affected cells in the hepatopancreas decreases with age in Penaeus vannamei (LeBlanc \& Overstreet 1990), the ratio of $\mathrm{BP}$ to shrimp DNA is lower in larger shrimp, necessitating the use of more totai DNA during PCR. This is likely the reason why it was necessary to use $300 \mathrm{ng}$ of template DNA to obtain visible amounts of the expected amplification product in the case of one PB-infected juvenile P. aztecus (Fig. 7, lane 10). For postlarval shrimp, we recommend digesting the hepatopancreas in $75 \mu \mathrm{l}$ of digestion buffer and using $5 \mu$ l of the final dissolved DNA for amplification isee 'Material and methods' for a detailed protocol of the sample digestion, extraction and precipitation procedure). For larger shrimp, the amount of tissue and digestion buffer should be scaled up although the volume of buffer used to dissolved the DNA should remain the same to increase the sample DNA concentration.

The presence of compounds in shrimp that inhibit DNA polymerase is a potential problem in using PCR for disease diagnosis. The nature of these compounds is not known but they are likely to be polyphenolic compounds or pigments that inhibit DNA polymerase activity. Such inhibitors may pose a problem when DNA is extracted from larger shrimp for diagnosis. Our results indicale that relative to postlarval shrimp, a larger amount of template DNA is required to obtain amplification when juvenile shrimp are tested for BP by PCR. This is likely to be due to the smaller ratio of viral to shrimp DNA in larger shrimp. When large shrimp are tested for BP, the use of a larger amount of hepatopancreas for DNA extraction and the use of an increased amount of total DNA during PCR enhance the likelihood of including inhibitors in the amplification reaction. Further research is needed to develop simple DNA isolation procedures that remove the inhibitory compounds more completely.

Acknowledgements. We thank Kenneth C. Stuck of the Guif Coast Research Laboratory for providing the shrimp used in the study and for sharing his expertise in culturing shrimp. This study was conducted in cooperation with the U.S. Department of Agriculture, CSRS, Grant No. 92-38808-6920.

\section{LITERATURE CITED}

Blissard GW, Rohrmann GR (1990) Baculovirus diversity and molecular biology. Ann Rev Entomol 35:127-155

Bruce LD, Redman RM, Lightner DV (1994) Application of gene probe to determinating target organs of a penaeid shrimp baculovirus using in situ hybridization. Aquaculture 120:45-51

Bruce LD, Redman RM, Lightner DV, Bonami JR (1993) Application of gene probes to detect a shrimp baculovirus in fixed tissue using in situ hybridization. Dis Aquat Org 17: 215-221

Couch JA (1974a) Free and occluded virus, similar to Baculovirus, in hepatopancreas of pink shrimp. Nature 247: 229-231

Couch JA (1974b) An enzootic nuclear polyhedrosis virus of pink shrimp: ultrastructure, prevalence, and enhancement. J Invertebr Pathol 24:311-331

Couch JA (1981) Viral diseases of invertebrates other than insects. In: Davidson EW (ed) Pathogenesis of invertebrate microbial diseases. Allanheld, Osmun Publishers, Totowa, NJ, p $125-160$

Couch JA (1989) The membranous labynnth in baculovirusinfected crustacean cells: possible roles in viral reproduction. Dis Aquat Org 7:39-53

Francki RIB, Fauquet CM, Knudison DL, Brown F (eds) (1991) Classification and nomenclature of viruses, 5th Report of the International Committee on Taxonomy of Viruses. Springer-Verlag, New York

Henson JM, French R (1993) The polymerase chain reaction and plant disease diagnosis. A Rev Phytopathol 31:81-109

Innis MA, Gelfand DH (1990) Optimization of PCRs. In: Innis MA, Gelfand DH, Sninsky JJ, White TJ (eds) PCR protocols: a guide to methods and applications. Academic Press San Diego, p 3-12

Johnson PT, Lightner DV (1988) Rod-shaped nuclear viruses of crustaceans: gut-infecting species. Dis Aquat Org 5: $123-141$

Jones DD, Bej AK (1994) Detection of foodborne microbial pathogens using polymerase chain reaction methods. In Griffin HG, Griffin AM (eds) PCR technology: current innovations. CRC Press, Boca Raton, p 341-365

LeBlanc BD, Overstreet RM (1990) Prevalence of Baculovirus penaei in experimentally infected white shrimp (Penaeus vannamei) relative to age. Aquaculture 87:237-242

Lewis DH (1986) An enzyme-linked immunosorbent assay (ELISA) for detecting penaeid baculovirus. J Fish Dis 9: $519-522$

Lightner DV (1993) Diseases of cultured penaelds shrimp. In: McVey JP (ed) CRC handbook of mariculture, 2nd edn, Vol 1, Crustacean aquaculture. CRC Press, Boca Raton, p 393-486

Lightner DV, Redman RM (1991) Hosts, geographic rancre and diagnostic procedures for the penaeid virus diseases of concern to shrimp culturists in the Americas. In: DeLoach P. Dougherty WJ, Davidson MA (eds) Frontiers in shrimp research. Elsevier Science Publishers BV. Amsterdam, p $173-196$

Lin JS, Wang SY (1993) The cloning and characterization of a shrimp cDNA probe for the virus Baculovirus penaei. Am Zool 33:49A

Malitschek B, Schartl M (1991) Rapid identification of recombinant baculoviruses using PCR. BioTechniques 11 : $177-178$

Martin WJ (1994) Infectious diseases. In: Mullis KB, Ferre F, Gibbs RA (eds) The polymerase chain reaction. Birkhauser, Boston, p 406-417 
Mullis K, Falcoma F, Scharf S, Snikl R, Horn G, Erlich H (1986] Specific amplification of DNA in vitro: the polymerase chain reaction. Cold Spring Harbor Symp Quant Biol 51:260

Overstreet RM, Stuck KC, Krol RA, Hawkins WE (1988\} Experimental infections with Baculovirus penaei in the white shrimp, Penaeus vannamei (Crustacea: Decapoda), as a broassay. J World Aquacult Soc 19:175-187

Richlik W, Spencer WJ, Rhoads RE (1990) Optimization of the annealing temperature for DNA amplification in vitro Nucl Acid Res 18:6409-6412

Rohrmann GF (1986) Polyhedrin structure. J Gen Virol 67 $1499-1513$

Saiki RK, Scharf S, Faloona F, Mullis KB, Horn GT, Erlich HA Arnheim $N$ (1985) Enzymatic amplification of $\beta$-globın genomic sequences and restriction site analysis for diagnosis of sickle cell anemia. Science 230:1350-1354

Stuck KC, Overstreet RM (1994) Effect of Baculovirus penaei

Responsible Subject Editor: J. E. Stewart, Dartmouth, Nova Scotia, Canada on growth and survival of experimentally infected postlarvae of the Pacific White Shrimp, Penaeus vannamei J Invertebr Pathol 64:18-25

Stuck KC, Wang SY (in press) Establishment and persistence of Baculovirus penaei (BP) infections in cultured Pacific white shrimp, Penaeus vannamei. J Invertebr Pathol

Summers MD (1977) Characterization of shrimp Baculovirus EPA Ecol Res Ser EPA-600/3-77-130. US EPA Gulf Brro; Environmental Res Lab, Gulf Breeze, p 1-35

Walsh PS, Metzger DA, Higuchi R (1991) Chelex 100 as a medium for simple extraction of DNA for PCR-based typing from forensic material. BioTechniques 10:506-513

Wyban JA (1992) Selective breeding of specific pathogen-free (SPF) shrimp for high health and increased growth. In: Fulks W, Main KL (eds) Diseases of cultured penaeid shrimp in Asia and the United States. The Oceanic Institute, Makapuu Point, Honolulu, p 257-268

Manuscript first received: August 21, 1995

Revised version accepted: November 6,1995 